\title{
Atypical Functional Properties of GluK3-Containing Kainate Receptors
}

\author{
David Perrais, Françoise Coussen, and Christophe Mulle \\ Laboratoire Physiologie Cellulaire de la Synapse, Centre National de la Recherche Scientifique Unité Mixte de Recherche 5091, Bordeaux Neuroscience \\ Institute, University of Bordeaux, 33076 Bordeaux, France
}

The properties of synaptic receptors determine their mode of action at presynaptic and postsynaptic loci. Here, we investigated the atypical biophysical properties of GluK3-containing kainate receptors, which contribute to presynaptic facilitation at hippocampal mossy fiber synapses. We show, using fast glutamate applications on outside-out patches and kinetic modeling, that the low sensitivity of GluK3 receptors for glutamate is attributable to fast desensitization of partially bound receptors. Consequently, these receptors can only be activated by fast transients of high glutamate concentration. In addition, GluK3 receptors are very sensitive to voltage-dependent block by intracellular spermine that precludes activation of substantial currents at potentials positive to $-50 \mathrm{mV}$. Two specific residues within the channel pore define this high-affinity site. Finally, GluK3 are calcium permeable in the same way as unedited GluK2 receptors. These receptors present unique properties among AMPA/kainate receptors that could reflect a specialized presynaptic function.

\section{Introduction}

Kainate receptors, forming a family of glutamate ionotropic receptors, play a role in a large proportion of synapses in the brain, sometimes as classical postsynaptic receptors, but most often by regulating presynaptic function (Lerma, 2006; Pinheiro and Mulle, 2006). In particular, at hippocampal mossy fiber terminals, kainate receptors likely composed of GluK2 and GluK3 (formerly referred as GluR6 and GluR7) are involved in various forms of short-term plasticity (Contractor et al., 2001; Schmitz et al., 2003; Pinheiro et al., 2007; Perrais et al., 2009) (but see Kwon and Castillo, 2008) and a discussion in the study by Sachidhanandam et al. (2009). Until now, despite a strong expression in various brain areas, a function for GluK3 receptors has only been found at the presynaptic level of the hippocampal mossy fiber synapse (Pinheiro et al., 2007), raising the possibility that this glutamate receptor subunit is tuned for presynaptic function. The functional constraints on presynaptic and postsynaptic receptor function are likely to be different. Postsynaptic receptors need to generate currents that are propagated throughout dendrites to contribute to somatic depolarization, whereas presynaptic receptors need only to affect presynaptic function locally.

GluK3 receptors display a very low sensitivity for glutamate compared with GluK2 receptors and to other AMPA/kainate receptors (Schiffer et al., 1997; Pinheiro et al., 2007). However, binding studies have shown similar affinities for the two kainate

\footnotetext{
Received June 10, 2009; revised 0ct. 27, 2009; accepted 0ct. 27, 2009.

This study was supported by grants from Centre National de la Recherche Scientifique, Conseil Régional d'Aquitaine, the European Commission (EUSynapse Project, Contract LSHM-CT-2005-019055), and Agence Nationale de la Recherche (Contract PreSynGlu 05-NEUR-033-01) (C.M.). We thank Jessica Ragues for producing the plasmid DNAs, Dr. Mark Mayer for the gift of plasmids, Dr. Nelson Rebola for sharing unpublished data, Drs. Marc Gielen and Pierre Paoletti for critically reading this manuscript, and the members of the Mulle Laboratory for discussions. Correspondence should be addressed to either David Perrais or Christophe Mulle at the above address. E-mail: david.perrais@u-bordeaux2.fr or christophe.mulle@u-bordeaux2.fr.

DOI:10.1523/JNEUROSCI.2724-09.2009

Copyright $\odot 2009$ Society for Neuroscience $\quad$ 0270-6474/09/2915499-12\$15.00/0
}

receptors (Bettler et al., 1992), suggesting that the gating mechanisms are different for the two receptors. More generally, many aspects of GluK3 functional properties, like deactivation kinetics, conductance, or calcium permeability, have not been directly evaluated. Unlike GluK1 and GluK2, GluK3 is not edited at the Q/R site (Lomeli et al., 1992), which makes it likely to produce calcium-permeable receptors, like unedited GluK2 receptors (Köhler et al., 1993; Burnashev et al., 1995).

The aim of this study was to determine critical GluK3-containing receptor properties in the context of synaptic activation. We have recorded currents evoked by fast glutamate applications on outside-out patches containing recombinant receptors composed of GluK2, GluK3, and GluK2/K3 subunits. We show with kinetic analysis and receptor modeling that the low sensitivity of GluK3 to glutamate is attributable to the unusual property of having a faster desensitization at subsaturating than at saturating glutamate concentration. Moreover, receptors composed of GluK3 are calcium permeable and more strongly blocked by intracellular polyamines than any other AMPA/kainate receptor. These properties are likely to have consequences on their mode of activation at excitatory synapses and on their ability to modulate glutamate release.

\section{Materials and Methods}

Cell culture and transfection. HEK293 cells (European Collection of Cell Culture) were grown and transfected as previously described (Coussen et al., 2005). Cells were cotransfected with green fluorescent protein (GFP) and the partially edited, most common version of GluK2, GluK2 $(\mathrm{V}, \mathrm{C}, \mathrm{Q})$, GluK3 $_{\mathrm{a}}$, or mutated forms of these receptors at a DNA ratio of 1:3, except for transfection with GluK2 $2_{\mathrm{a}}$ (Y490C,L752C) or GluK3 $3_{\mathrm{a}}$ (H492C,L753C), which are in a vector expressing GFP under a downstream internal ribosome entry site (Weston et al., 2006). For experiments on heteromeric GluK2/K3 receptors, cells were transfected with GFP, $\operatorname{GluK}_{\mathrm{b}}(\mathrm{Q})$, and GluK3 ${ }_{\mathrm{a}}$ at a DNA ratio of 1:1.5:1.5. Cells were used 1-3 d after transfection, and replated the day before recording for lifted cells, or 1-2 $\mathrm{d}$ before recording for outside-out patches. 
Mutagenesis. Clones corresponding to $\mathrm{GluK} 2_{\mathrm{a}}(\mathrm{Q}), \mathrm{GluK} 2_{\mathrm{b}}(\mathrm{Q})$, and GluK3 a were described previously (Coussen et al., 2005; Pinheiro et al., 2007). Site-directed mutagenesis was performed using QuickChange XL kit (Stratagene) with specific oligonucleotides corresponding to each mutant [oligonucleotide forward sequences for the following: GluK3(VA): CCTTGTTGCATCAGGGCGCCCACTCCAAACCAGAAGC primed on GluK3 $3_{\mathrm{a}}$; GluK3(V): GGTTTGGAGTGGGATCCCTGATGCAACAAGG primed on GluK3 ; GluK3(A): GGTTTGGAATGGGCGCCCTGATGCAACAAGG primed on GluK3 ; GluK2(MS): GCTAAATAGTTTCTGGTTTGGAATGGGATCCCTCATGCAGCAAGG primed on GluK2 $2_{a}$; GluK2(DAGEMS): first mutagenesis to make GluK2(DAGMS) with CCCTATGAGTGGTATGACGCACACCCTTGCAACCCTGGATCCGACGTGGTGG primed on GluK2(MS) and second round of mutagenesis with CCCTGGATCGGAAGTGGTGGAAAACAATTTTACC primed on GluK2(DAGMS)]. The K2e/3i chimera was constructed by subcloning the $\mathrm{C}$ terminus domain of GluK3 $\mathrm{a}$ (starting at A799, in the M4 domain, with a Nae1 site) into GluK2(DAGEMS). Conversely, the $\mathrm{K} 3 \mathrm{e} / 2 \mathrm{i}$ chimera was constructed by subcloning the $\mathrm{C}$ terminus domain of GluK2 2 starting at A798) into the mutated GluK3(NPDDVA), with all six residues in the M1-M3 domain mutated. Finally, K3e/2i (MS) was made by directed mutagenesis with a forward primer (GGTTTGGAATGGGCTCCCTGATGC) primed on K3e/2i DNA. DNAs were verified by restriction analysis and sequencing.

Electrophysiological recordings. Brightly fluorescent, isolated cells were selected for recording. Cells were bathed in a solution containing the following (in mM): $150 \mathrm{NaCl}, 2 \mathrm{KCl}, 2 \mathrm{MgCl}_{2}, 2 \mathrm{CaCl}_{2}, 10$ glucose, 10 HEPES, equilibrated to $\mathrm{pH} 7.4$ with $\mathrm{NaOH}$. Cells were recorded in whole-cell or outside-out patch mode, and placed under the flow of a theta tube pulled to a final opening of $\sim 100 \mu \mathrm{m}$ mounted on a piezoelectric translator (Burleigh or Physik Instrumente). Currents were evoked by applications of $30 \mathrm{~mm}$ glutamate for $100 \mathrm{~ms}$ every $20 \mathrm{~s}$, unless otherwise indicated. Voltage was held at $-40 \mathrm{mV}$ for cells expressing GluK2 or $-80 \mathrm{mV}$ for cells expressing GluK3, unless otherwise indicated. Currents were filtered at $2.9 \mathrm{kHz}$ and recorded at a sampling frequency of $20 \mathrm{kHz}$ by an EPC10 amplifier (HEKA). Up to four different glutamate concentrations were applied to a cell or an outside-out patch with a manual valve. The exchange between two different concentrations was completed within $2 \mathrm{~min}$. The intracellular solution contained the following (in mM): $140 \mathrm{CsCH}_{3} \mathrm{SO}_{3}, 2 \mathrm{MgCl}_{2}, 10$ HEPES, 10 EGTA, $4 \mathrm{Na}_{2} \mathrm{ATP}$, 0.1 spermine (or less, see below). Since ATP is a good chelator of spermine, this solution has an expected concentration of free spermine of $\sim 30$ $\mu \mathrm{M}$ (Watanabe et al., 1991). This value is slightly lower than the one estimated for HEK293 cells (Bowie and Mayer, 1995), but the high capacity of spermine inside these cells is likely to compensate for this difference during whole-cell recordings. Indeed, the values obtained for the voltage at half-conductance $\left(V_{\text {half }}\right)$ were similar in this and previous studies (Bowie and Mayer, 1995; Panchenko et al., 1999). Similarly, solutions containing $4 \mathrm{~mm}$ ATP and 0.1 or $1 \mu \mathrm{M}$ spermine were estimated to contain 0.03 and $0.3 \mu \mathrm{M}$ free spermine, respectively. Because of the added ATP, solutions with no added spermine will chelate remaining spermine rapidly, and therefore the slow washout kinetics observed for GluK3 binding genuinely represents slow unbinding from the receptor. All chemicals were from Sigma-Aldrich. Domoate and cyclothiazide were from Tocris Bioscience, and UBP310 was a kind gift from David Jane (Medical Research Council, Bristol, UK).

Calcium imaging. Fractional calcium currents were measured according to the method of Neher and coworkers (Burnashev et al., 1995; Jatzke et al., 2003). Transfected cells were recorded with a solution containing the following (in mM): $140 \mathrm{CsCH}_{3} \mathrm{SO}_{3}, 10 \mathrm{HEPES}, 1$ fura-2 (pentapotassium salt). Agonists were applied through a two-barrelled pipette pulled to $\sim 100 \mu \mathrm{m}$ operated with microfluidic valves (Lee Company). This method of application proved more reliable on adherent cells than translation of the application pipette and gave exchange time in the $100 \mathrm{~ms}$ range (see Fig. $8 D, E$ ). After establishment of whole-cell recording, agonist ( $30 \mathrm{~mm}$ glutamate or $10 \mu \mathrm{M}$ domoate) was applied once for $2 \mathrm{~s}$, to measure the amplitude of the recorded current. Cells were discarded if this amplitude was $<100 \mathrm{pA}$ at $-80 \mathrm{mV}$ [ 13 of 22 cells for GluK3(H492C,L753C)]. Cells were held for 6-8 min to allow complete dialysis of the pipette solution into the cell cytoplasm, and simultaneous current and fura-2 fluorescence recordings were performed. Fura-2 fluorescence was excited by a xenon lamp (Olympus) with a 380/15 nm excitation filter, a $410 \mathrm{~nm}$ dichroic mirror (Omega Optical), and collected with a 525/25 nm emission filter (Chroma). Before whole-cell recording, the cell fluorescence, despite the presence of GFP, was $<8 \%$ of the fluorescence of the dialyzed cell and was subtracted from the image. The fura-2 fluorescence was recorded by a Quantem 2 camera (Roper Scientific) operated in stream mode by MetaMorph 7 (Roper Scientific). Images were taken every $50 \mathrm{~ms}$ with a camera gain of 1 , and the fluorescence in a $13.5-\mu \mathrm{m}$-diameter circle was recorded. At the end of each recording session, to correct for variations in lamp power, the fluorescence of beads (Fluoresbrite BB; Polysciences) was measured, and the cell fluorescence was expressed in bead units (BU).

To transcribe fura- 2 fluorescence variations into fractional current, we recorded cells expressing GluA1 in conditions in which the only ion crossing the channels is calcium. We chose GluA1 since GluK2 is inactive in the absence of extracellular sodium (Paternain et al., 2003). These cells were bathed in a solution containing the following (in $\mathrm{mm}$ ): 150 $\mathrm{N}$-methyl glucamine chloride, $10 \mathrm{HEPES}, 10 \mathrm{CaCl}_{2}$, equilibrated to $\mathrm{pH}$ 7.4 with $\mathrm{HCl}, 315$ mosm. The pipette solution contained the following (in mM): $145 \mathrm{~N}$-methyl glucamine chloride, 10 HEPES, 1 fura-2 (pentapotassium salt). Cells were transfected with the flip splice variant of GluR1 and DsRed. Currents were evoked by application of $10 \mathrm{~mm}$ glutamate in the presence of $100 \mu \mathrm{M}$ cyclothiazide for $1 \mathrm{~s}$, which elicited charges of $73 \pm 11 \mathrm{pC}$ and fura- 2 fluorescence decreases of $1.6 \pm 0.2 \mathrm{BU}$ $(n=5)$, leading to a ratio of $2.15 \times 10^{-2} \mathrm{pC} / \mathrm{BU}$ for calcium changes elicited by purely calcium currents. This ratio was then used to calculate the fractional current carried by calcium in GluK2 and GluK3 receptors (see Fig. 8).

Data analysis. All electrophysiological recordings were analyzed with Igor Pro 5 (Wavemetrics). Current amplitudes and rise time were measured with built-in tools, and current decay was measured with exponential fit using least-squares algorithm. Conductance was calculated as a ratio between current and holding voltage - reversal voltage $\left(V_{\text {rev }}\right)$. The latter parameter was measured as $+8 \mathrm{mV}$ in our recording solution with the edited form of GluK2, GluK2 ${ }_{\mathrm{a}}(\mathrm{R})$, which is not blocked by spermine. To determine $V_{\text {half }}$, the voltage at half-channel block, the conductancevoltage curves between -200 and $0 \mathrm{mV}$ were fitted with a sigmoidal function $G(V)=G_{\max } / 1+\exp \left(\left(V-V_{\text {half }}\right) / k_{b}\right)$. These values of $V_{\text {half }}$ and $k_{b}$ yield to an estimate of $K_{\mathrm{d}(0)}$, the dissociation constant for spermine at $0 \mathrm{mV}$, with $K_{\mathrm{d}(0)}=[$ spermine $] \cdot \exp \left(V_{\text {half }} / k_{b}\right)$ (Bowie and Mayer, 1995; Panchenko et al., 1999).

Channel conductance $\gamma$ and open probability at the current peak $P_{\text {o,peak }}$ were estimated by nonstationary fluctuation analysis (NSFA) as described by Traynelis and Wahl (1997). Stable epochs of 60-120 applications (30 mu glutamate) on cells expressing GluK3 were averaged in groups of 10 successive applications, and subtracted from each individual trace (see Fig. $2 C$ ). The variance of these subtracted currents was computed for time intervals on a log scale during the current decay phase. For each cell, the variance $\sigma^{2}$ in these intervals was plotted against the average current $I$ and fit with the equation $\sigma^{2}=i I-I^{2} / N$, with $i$ the elementary current and $N$ the number of channels. Consequently, $P_{\text {o,peak }}=I_{\text {peak }} / N i$ and $\gamma=i /\left(V_{\text {hold }}-V_{\text {rev }}\right)$. The variance analysis was performed with programs written in Matlab 7 (Mathworks).

Receptor modeling. Modeling of GluK2 and GluK3 receptors was done using ChanneLab 2.04 (Synaptosoft) with either Runge-Kutta numerical integration or Monte Carlo simulation for NSFA, with a time interval of $10 \mu \mathrm{s}$, for 5000 receptors held at $-80 \mathrm{mV}$. Applications of glutamate were filtered at $5 \mathrm{kHz}$ to simulate a solution exchange time of $100 \mu$ s, typical of the exchange time measured in our experimental system (Barberis et al., 2008). In Figure 3, amplitudes and kinetic parameters were measured using the macroscopic analysis feature of ChanneLab software. NSFA on simulated currents (filtered at $2 \mathrm{kHz}$ ) was performed as described above for the experimental data. The rationale of the model architecture and the choice of rate constants follow the principles exposed by Robert and Howe (2003) and Barberis et al. (2008). In particular, the set of rate constants presented here is certainly not unique, but could adequately fit the experimental data, and could predict the measured $P_{\text {o,peak }}$. The 
A

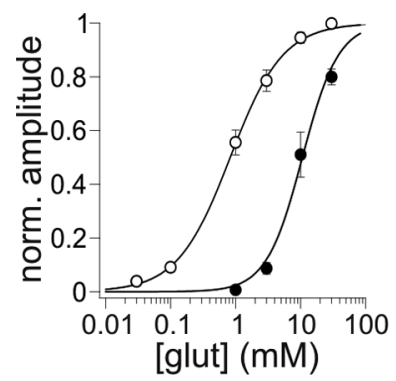

B

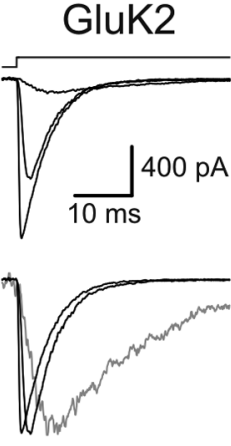

D

C

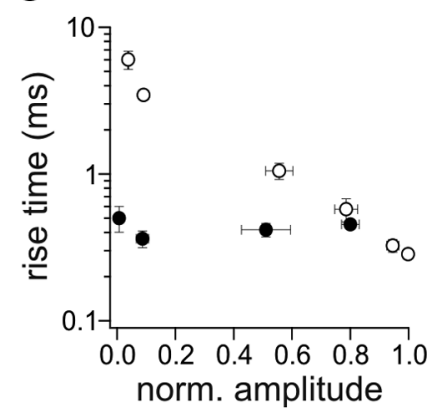

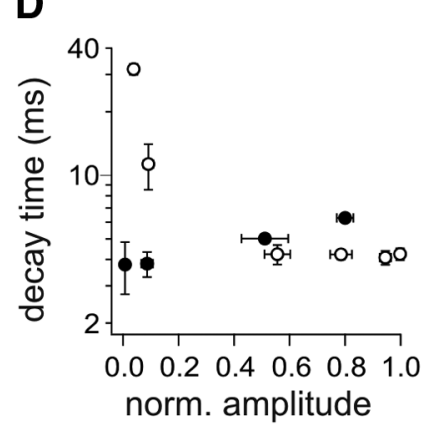

Figure 1. Desensitization of GluK3 receptors is fast at all levels of receptor saturation. $\boldsymbol{A}$, Glutamate dose-response curves for GluK2(Q) (white circles) and GluK3 (black circles) recorded in outside-out patches. The lines are fits with the Hill equation, with $\mathrm{EC}_{50}$ values of 0.86 and $10.5 \mathrm{~mm}$, respectively. $\boldsymbol{B}$, Left, Currents evoked by 30,1 , and $0.1 \mathrm{~mm}$ glutamate on an outside-out patch containing GluK2(Q) receptors. On bottom, the same traces are normalized. The trace at $0.1 \mathrm{~mm}$ is light gray. Right, Currents evoked by 30,3 , and $1 \mathrm{~mm}$ glutamate on a patch containing GluK3 receptors. On the normalized traces (right), the response to $1 \mathrm{~mm}$ glutamate is light gray. $\boldsymbol{C}, \boldsymbol{D}$, Relationship between current amplitude, normalized to maximum (as in $\boldsymbol{A}$ ), and $20-80 \%$ rise time (C) or decay time (D) for GluK2 (white symbols) and GluK3 (black symbols). Error bars indicate SEM.

present models also satisfy microscopic reversibility. Consequently, the different relationships between $\delta_{1}$ and $\delta_{2}$ will lead to different unbinding rates $k_{-2}$ for the two receptors.

Synaptic release of glutamate at the mossy fiber was simulated as a function of time $t$ and radial distance from the release site $r$ using the calculation of Barbour and Häusser (1997) for a synaptic cleft of height $h$ as [glut] $=\left(M / 4.10^{-15} \pi N h D t\right)^{*} \exp \left(-r^{2} / 4 D t\right)$, where $M$ is the number of glutamate molecules contained in a vesicle, $N$ is Avogadro's number, and $D$ is the glutamate diffusion coefficient in the synaptic cleft. We took as in common estimates $h=20 \mathrm{~nm}, M=4700$, and $D=0.5 \mu \mathrm{m}^{2} \mathrm{~ms}^{-1}$ (Barbour and Häusser, 1997). This latter value is lower than that in free solution, but more likely reflects the values in the synaptic cleft (Nielsen et al., 2004; Savtchenko and Rusakov, 2004). We have not included glutamate binding sites within the cleft that could cause buffered diffusion or glutamate uptake. Such a choice was made in a previous model of the cerebellar mossy fiber synapse (Nielsen et al., 2004). In support of this choice, application of the glutamate receptor blocker THA [L(-)-threo3-hydroxyaspartic acid] $(200 \mu \mathrm{M})$ did not affect mossy fiber EPSCs (N. Rebola, unpublished observations).

\section{Results}

\section{Kinetic properties of GluK3 receptors}

Kainate receptors composed of GluK3 have a particularly low sensitivity to glutamate. The $\mathrm{EC}_{50}$ for glutamate is $>10$-fold higher than GluK2 receptors (Schiffer et al., 1997; Pinheiro et al., 2007). However, these previous experiments were performed on lifted whole cells in which the time to exchange agonist solution is in the range of $0.5-1 \mathrm{~ms}$ (Barberis et al., 2008), which could explain part of the difference in glutamate sensitivity of these fast desensitizing receptors. We determined the $\mathrm{EC}_{50}$ of glutamate applications on outside-out patches, in which faster solution exchange can be achieved (0.1-0.2 ms). We found that GluK3 receptors were much less sensitive to glutamate than GluK2 receptors (Fig. $1 A, B$ ), with $\mathrm{EC}_{50}$ values of $10.6 \pm 0.2 \mathrm{~mm}(n=4$; Hill's coefficient $h=1.56$ ) for GluK3 and $0.86 \pm 0.06 \mathrm{~mm}(n=5, h=1.01)$ for GluK2. These values are very close to the ones found with whole cells [ 12.4 and 0.74 $\mathrm{mM}$, respectively (Pinheiro et al., 2007)]. Therefore, even with fast exchange time, GluK3 receptors are activated by greater glutamate concentrations than any other AMPA/kainate receptors.

What could be the mechanism for such a difference? We examined in more detail the current kinetics at the different glutamate concentrations. For GluK2 receptors, subsaturating concentrations of glutamate evoked currents that were slower than those evoked by saturating concentrations (Fig. 1B) (Heckmann et al., 1996; Bowie, 2002; Barberis et al., 2008). Rise times increased steadily when the glutamate concentration decreased (Fig. 1C), and decay times increased steeply when the glutamate concentration was less than the $\mathrm{EC}_{50}$ (Fig. $1 B, D$ ). At the lowest concentration tested $(30 \mu \mathrm{M})$, rise times and decay times were markedly higher than at $30 \mathrm{~mm}$ (decay times, $31.8 \pm 1.9 \mathrm{~ms}, n=4$ at $30 \mu \mathrm{M}$, vs $4.2 \pm 0.3 \mathrm{~ms}, n=13$ at 30 $\mathrm{mm})$. In contrast, for GluK3 receptors, applications of glutamate at various concentrations induced currents with similar rise times (Fig. 1C) and with decay times that decreased in parallel with glutamate concentration (Fig. $1 B, D$ ) (decay times, $6.3 \pm 0.2$ $\mathrm{ms}, n=14$, for $30 \mathrm{~mm}$; $3.8 \pm 0.2 \mathrm{~ms}, n=4$, for $3 \mathrm{~mm} ; 4.8 \pm 1.1$ $\mathrm{ms}, n=4$, for $1 \mathrm{~mm}$; decay significantly larger at $30 \mathrm{~mm}$ vs lower concentrations; $p<0.01$ ). We tested the hypothesis that fast desensitization of GluK3 receptors might curtail receptor activation at lower glutamate concentration, producing lower apparent glutamate sensitivity for GluK3 despite similar equilibrium binding constants (Bettler et al., 1992). Consistent with this hypothesis, GluK3 receptors are slightly more sensitive to desensitization by steady-state applications of glutamate than GluK2 receptors (Fig. 2A). To address the role of desensitization in determining glutamate sensitivity quantitatively, we constructed kinetic models of GluK2 and GluK3 based on previously published model architectures for AMPA/kainate receptors (Fig. 3A) (Heckmann et al., 1996; Robert and Howe, 2003; Barberis et al., 2008). To constrain these models, we determined other important kinetic parameters, recovery from desensitization, deactivation after short agonist pulses, single channel conductance, and open probability at the peak $P_{\text {o,peak }}$ (Fig. $2 B-D$ ).

First, we compared the kinetics of recovery from desensitization for GluK2 and GluK3 receptors. We measured the ratio of current amplitudes induced by a pulse of glutamate $(30 \mathrm{~mm})$ for $50 \mathrm{~ms}$ at different time intervals (Fig. 2 B). One second after complete desensitization, the test pulse amplitude was $53 \pm 2 \%(n=$ 3 ) of control for GluK3, larger than for GluK2 (30 $\pm 5 \%$; $n=3)$. Overall, the recovery time course of GluK3 receptors is slightly faster than the one of GluK2 (Fig. 2 B) (Heckmann et al., 1996; Bowie and Lange, 2002; Barberis et al., 2008). Second, the deactivation rate of GluK3 receptors measured with brief $(0.5 \mathrm{~ms})$ 
A

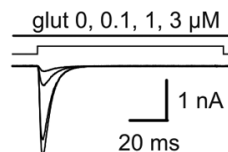

B
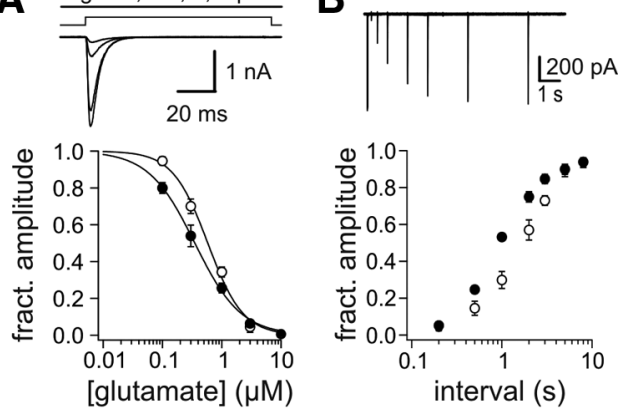

C
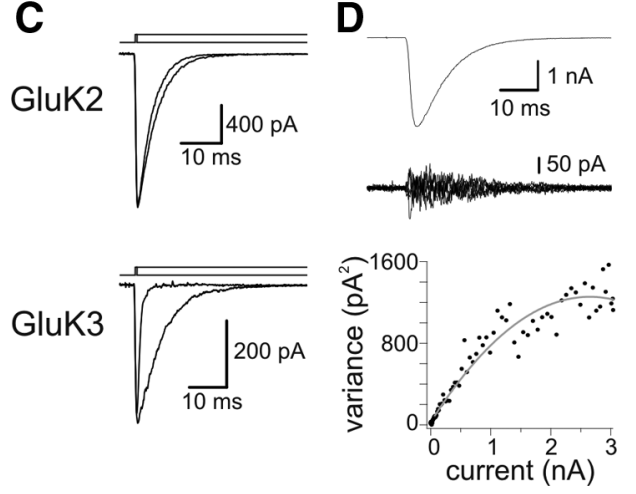

Figure 2. Measures of GluK3 kinetic parameters. $\boldsymbol{A}$, Effect of preapplication of glutamate $(0.1,1$, and $3 \mu \mathrm{M})$ on currents evoked by glutamate application ( $30 \mathrm{~mm}$ ) on a cell expressing Gluk3. Bottom, Plots of the relative amplitude after steady-state desensitization by glutamate for GluK2 (white circles) and GluK3 (black circles). The lines are fits with $\mathrm{IC}_{50}$ values of 580 and $350 \mathrm{~nm}$ and Hill's coefficients of 1.47 and 1.11, respectively. $\boldsymbol{B}$, Top, Paired applications of glutamate $(30 \mathrm{~mm} ; 50 \mathrm{~ms})$ separated by intervals ranging from $200 \mathrm{~ms}$ to $8 \mathrm{~s}$ on a lifted cell expressing GluK3. Bottom, Plot of the amplitude ratio between the two successive responses versus time interval for GluK2 (white circles) and GluK3 (black circles). Error bars indicate SEM. C, Currents evoked on outside-out patches with GluK2 and GluK3 by long $(100 \mathrm{~ms})$ and short $(0.5$ $\mathrm{ms}$ ) applications of $30 \mathrm{~mm}$ glutamate. $\boldsymbol{D}$, Nonstationary fluctuation analysis performed on a cell expressing GluK3. Top, Average current evoked by $30 \mathrm{~mm}$ glutamate. Below is the difference between five consecutive sweeps and the average. Bottom, Plot of variance versus average current. The curve is fitted by a parabola that gives $i=0.94 \mathrm{pA}, N=5670$, and $P_{0 \text { peak }}=0.57$

glutamate $(30 \mathrm{~mm})$ applications was very fast (Fig. $2 C$ ) with a time constant $\tau=1.0 \pm 0.1 \mathrm{~ms}(n=5)$. This is shorter than the decay of GluK2 receptors $(3.5 \pm 0.1 \mathrm{~ms} ; n=5)$. For GluK3 receptors, desensitization was much slower than deactivation, in sharp contrast with GluK2 receptors. Finally, we used NSFA (Traynelis and Wahl, 1997) on stable lifted cell recordings (30 mM glutamate) to estimate $P_{\text {o,peak }}$ and the single-channel chord conductance $\gamma$. Variance-average current curves were well fitted by quadratic functions (Fig. $2 D$ ). For five cells, we obtained $P_{\text {o,peak }}=0.50 \pm 0.03$ and $\gamma=12.9 \pm 1.2 \mathrm{pS}$. These values are smaller than those reported for GluK2: $P_{\text {o,peak }}$ of 0.65 and $\gamma$ of 16 pS (Traynelis and Wahl, 1997).

\section{Model of GluK3 kinetics}

To model the kinetic behavior of GluK2 and GluK3 receptors, we used the model architecture developed by Robert and Howe (2003) for AMPA receptors and adapted for GluK2 receptors by Barberis et al. (2008). In these schemes, receptors have four agonist binding sites because of their tetrameric structure and three open states with three corresponding conductance levels of 8, 16, and 24 pS for GluK2 receptors (Swanson et al., 1996), arising from two- to four-ligand bound states (Fig. 3A). We first adapted the model of GluK2 receptors to match our experimental data. The previously used model (Barberis et al., 2008) accurately re- produced the desensitization, deactivation, and recovery from desensitization kinetics with a saturating concentration of glutamate. However, simulated currents at low glutamate concentrations had faster rise times and slower decay times that the experimental data. Uniform changes of the desensitization rates $\left(\delta_{n}\right)$ or the binding rates $\left(k_{n}\right)$ could not give satisfactory results. Lowering $\delta_{1}$ alone slowed desensitization at low agonist concentration, but this was true only at very low concentration $(<10$ $\mu \mathrm{M})$. To obtain a significant increase in rise time and decay time already at $100 \mu \mathrm{M}$, the most efficient way was to lower the binding rate of the first glutamate molecule $\left(k_{0}\right)$ as well. Comparable with the model of Robert and Howe (2003) for AMPA receptors, we added desensitized states $\left(D^{\prime} 2-4\right)$ that did not play an important role for the GluK2 model, but were most necessary for the GluK3 model (see below). These three changes, and minor changes to the other rate constants compared with Barberis et al. (2008) (Table 1), gave very good approximation of the experimental data for GluK2 receptors (Fig. 3B). Simulations reproduced the $\mathrm{EC}_{50}$ (Fig. $3 D$ ), desensitization kinetics for different glutamate concentrations (Fig. 3E), steady-state desensitization (Fig. $3 F$ ), recovery from desensitization (Fig. $3 G)$, and $P_{\text {o,peak }}$ at saturating concentration (0.63, determined by NSFA using Monte Carlo simulation). Thus, unlike AMPA receptors, which have similar desensitization kinetics across all glutamate concentrations that translate into similar values of $\delta$ for all bound states (Robert and Howe, 2003; Robert et al., 2005), GluK2 receptors bind glutamate and desensitize faster when more agonist sites are bound, suggesting a prominent positive allosteric mechanism of binding and desensitization for these receptors.

To model GluK3 receptor gating, we conserved the model architecture of the GluK2 model. The three open states have a conductance of $6.5,13$, and $19.5 \mathrm{pS}$ to match the experimental data of $13 \mathrm{pS}$ average conductance (Fig. 2C). GluK3 receptors have a much faster deactivation rate than GluK2 receptors (Fig. $2 B$ ), which would translate into an increased closing rate $\alpha$. Moreover, they desensitize faster at lower glutamate concentration, which would mean that $\delta_{1}>\delta_{2-4}$. Indeed, we could find a good match of the experimental data with $\alpha$ increased 10 times and $\delta$ decreasing with increased number of bound molecules (i.e., $\left.\delta_{1}>\delta_{2}>\delta_{3-4}\right)$. We increased the recovery from desensitization rates $\left(\gamma_{1-2}\right)$ to match the recovery from desensitization data. Finally, simulations without $\mathrm{D}^{\prime}$ states led at low glutamate concentration (1-3 mM) to currents that had a relatively large sustained component. Addition of $\mathrm{D}^{\prime}$ states corrected this problem, without affecting the response at high concentration or the recovery from desensitization. These modifications and a small decrease in the binding rate $\mathrm{k}_{1}$ (Table 1 ) were sufficient to provide good fit to the experimental data (Fig. 3). Model simulations reproduce the fast deactivation kinetics (Fig. 3C), the high $\mathrm{EC}_{50}$ and large Hill's coefficient (Fig. 3D), the acceleration of desensitization at low glutamate concentration (Fig. $3 C, E$ ), steady-state desensitization (Fig. $3 F$ ), and the recovery from desensitization (Fig. 3G). Finally, Monte Carlo simulations analyzed with NSFA yielded estimates of single-channel conductance $(13.6 \mathrm{pS})$ and $P_{\mathrm{o}, \max }(0.46)$ that were similar to the experimental estimates.

\section{Modeling synaptic activation of kainate receptors}

This modeling study shows that the low sensitivity of GluK3 receptors to glutamate is mainly attributable to fast entry into desensitization, and not a low intrinsic affinity. Moreover, it 
A

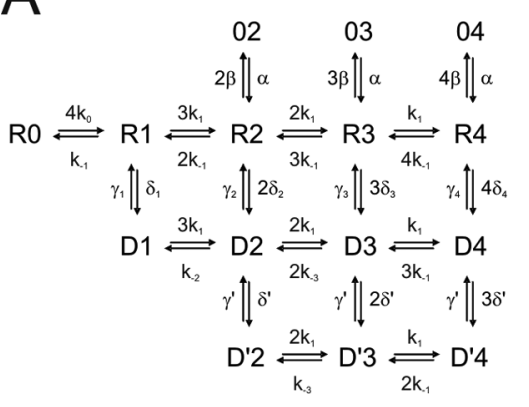

D
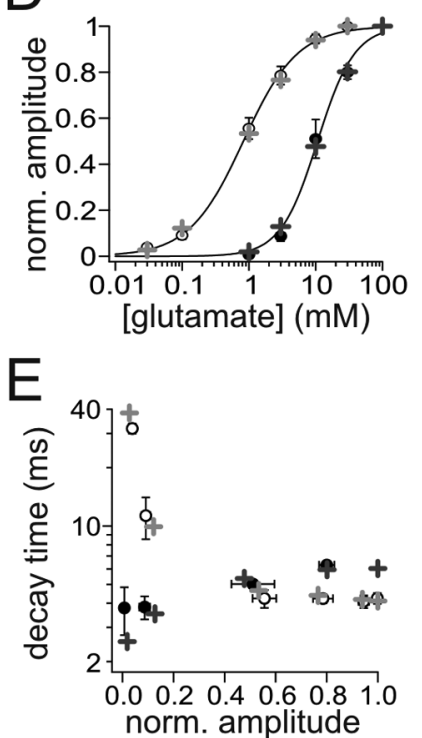
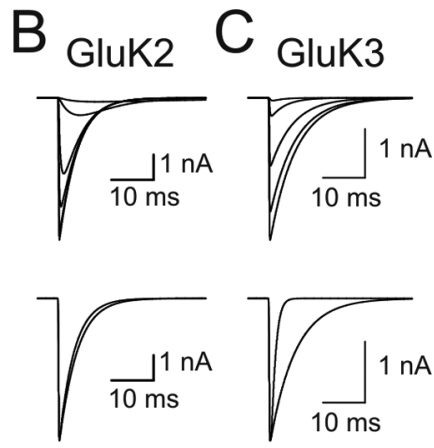

F

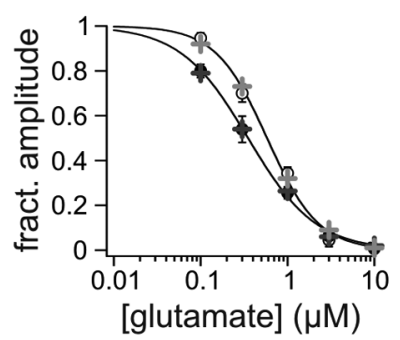

$G$

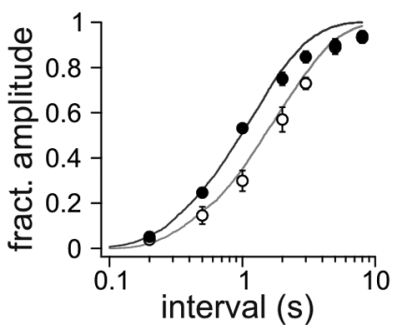

Figure 3. A model of GluK3 kinetics. $A$, Kinetic model of GluK2 and GluK3 receptors. The parameters used for these two receptors are listed in Table 1 . $\boldsymbol{B}$, Simulated GluK2 receptor-mediated currents ( 5000 channels; $-80 \mathrm{mV}$ ) evoked by application of glutamate $(0.03,0.1,1,3,10$, and $30 \mathrm{~mm})$ for $50 \mathrm{~ms}$. Bottom, Simulated currents evoked by applications of $30 \mathrm{~mm}$ glutamate for 50 and $0.5 \mathrm{~ms}$. C, Simulated GluK3 receptor-mediated currents evoked by application of glutamate $(1,3,10,30$, and $100 \mathrm{~mm})$ for $50 \mathrm{~ms}$. Bottom, Simulated currents evoked by applications of $30 \mathrm{~mm}$ glutamate for 50 and 0.5 ms. D-G, Measures of the simulated GluK2 (light gray crosses) and GluK3 (dark gray crosses) superimposed on the experimental data: dose-response curves (reproduced from Fig. $1 A$ ) (D), relationship between normalized amplitude and decay kinetics (as in Fig. 1D) $(\boldsymbol{E})$, steady-state desensitization by glutamate (as in Fig. $2 A$ ) $(\boldsymbol{F}$ ), and recovery from desensitization $(\boldsymbol{G})$, determined by the fraction of unbound receptors after application of $30 \mathrm{~mm}$ glutamate for $50 \mathrm{~ms}$ for simulated GluK2 (light gray curve) and GluK3 receptors (dark gray curve) superimposed on the experimental data (as in Fig. 2B). Error bars indicate SEM.

suggests that GluK3 receptors are very prone to desensitization from slow rises in glutamate concentration. These slow changes are expected to occur when glutamate diffuses large distances away from the release site (Barbour and Häusser, 1997). To test this idea further, we modeled the activation of receptors by neurotransmitter released in hippocampal mossy fibers contacting pyramidal cells, in which GluK3-containing receptors modulate release (Pinheiro et al., 2007). In the rat, these complex synapses have a diameter of $2-5 \mu \mathrm{m}$ and contain on average 25 active zones that have a surface of $0.1 \mu \mathrm{m}^{2}$ and are separated by $0.45 \mu \mathrm{m}$ on average (Rollenhagen et al., 2007). We chose to represent schematically this synapse by an array of circular active zones $(0.18$ $\mu \mathrm{m}$ radius) separated evenly by $0.5 \mu \mathrm{m}$ (Fig. $4 A$ ). Therefore, one active zone located close to the center of the bouton has six nearest neighbors located $0.5 \mu \mathrm{m}$ apart and 12 neighbors at $\sim 1 \mu \mathrm{m}$ (Fig. $4 A$, dotted circles). The rest of active zones are located $\sim 1.5$ $\mu \mathrm{m}$ away. We chose commonly used parameters to simulate the instantaneous release of the contents of one vesicle at a site lo-

cated in the center (for a discussion of the parameters, see Materials and Methods). We examined the simulated time course of glutamate concentration in four locations: at the release site, and $0.5,1$, and 1.5 $\mu \mathrm{m}$ away. Even $1 \mu \mathrm{m}$ away from the release site, the glutamate concentration peaks above $30 \mu \mathrm{M}$ and is sustained above $10 \mu \mathrm{M}$ for several milliseconds (Fig. $4 B$ ). Consequently, receptors located in neighboring postsynaptic densities (PSDs) could be significantly activated. We tested this possibility with models of GluK2 and GluK3 developed in this study. Contrary to GluK2, activation of GluK3 away from the release site was negligible (Fig. 4C,D, G). Therefore, GluK3 receptors would be activated only very close to the site of vesicle release. In addition, we examined the AMPA receptors GluA1 with the kinetic model developed by Robert and Howe (2003). Like for GluK2, significant portions of receptors were activated outside of the release site (Fig. 4E,G) despite kinetics that are faster for GluAl than for GluK2. Finally, we tested the activation of GluK2/K5 modeled by Barberis et al. (2008) that would correspond to postsynaptic kainate receptors. As expected from the study by Barberis et al. (2008), the current kinetics is much slower than for the other AMPA/kainate receptors (Fig. $4 C-E)$. Moreover, GluK2/K5 receptors located outside of release sites were very well activated (Fig. $4 F, G$ ), with time to peak that are several milliseconds. This mechanism of receptor activation from multiple zones away from the release site could explain the large rise time observed for kainate receptor-mediated postsynaptic currents in this synapse (Cossart et al., 2002; Marchal and Mulle, 2004). Indeed, modeling the summation of the currents arising from all PSDs showed that GluK3 receptor activation was the fastest and GluK2/K5 receptor activation reached a peak in several milliseconds, much longer than GluA1 receptors (Fig. $4 H$ ).

Voltage-dependent block of GluK3 by intracellular spermine GluK3 receptors show such strong inward rectification that, unlike other AMPA/kainate receptors, they do not pass outward current at positive potentials (Schiffer et al., 1997; Pinheiro et al., 2007). This property has permitted the specific study of heteromeric GluK2/3 receptors (Pinheiro et al., 2007; Perrais et al., 2009). We described the voltage-dependent behavior of GluK3 receptors more precisely by recording currents at voltages from -200 to $+100 \mathrm{mV}$ (Fig. $5 A, B$ ). The conductance reached a plateau only at potentials below $-180 \mathrm{mV}$ (Fig. $5 C$ ). The conductance-voltage relationship was sigmoidal, with a voltage at half-conductance $\left(V_{\text {half }}\right)$ of $-81.1 \pm 5.1 \mathrm{mV}(n=8)$, considerably lower than GluK2(Q) $\left(V_{\text {half }}=-34.7 \pm 2.7 \mathrm{mV} ; n=\right.$ $7)$, with slope factors $\left(k_{b}\right)$ of $21.6 \pm 1.4$ and $22.5 \pm 1.3 \mathrm{mV}$, respectively. In keeping with previous studies demonstrating the 
Table 1. Rate constant values for modeling GluK2 and GluK3 channels

\begin{tabular}{lcc}
\hline & GluK2 & GluK3 \\
\hline$k_{0}$ & $6.25 \times 10^{5}$ & $6.25 \times 10^{5}$ \\
$k_{1}$ & $1.5 \times 10^{7}$ & $1.0 \times 10^{7}$ \\
$k_{-1}$ & 1800 & 1800 \\
$k_{-2}$ & 180 & $2.16 \times 10^{4}$ \\
$k_{-3}$ & 1800 & 964 \\
$\beta$ & 7500 & 7500 \\
$\alpha$ & 800 & 8000 \\
$\delta_{1}$ & 350 & $3.0 \times 10^{5}$ \\
$\delta_{2}$ & 3500 & $2.5 \times 10^{4}$ \\
$\delta_{3}$ & 3500 & 200 \\
$\delta_{4}$ & 3500 & 200 \\
$\delta^{\prime}$ & 200 & 200 \\
$\gamma_{1}$ & 0.6 & 140 \\
$\gamma_{2}$ & 0.6 & 140 \\
$\gamma_{3}$ & 0.6 & 0.6 \\
$\gamma_{4}$ & 0.6 & 0.6 \\
$\gamma^{\prime}$ & 40 & 10 \\
\hline
\end{tabular}

All rates are in $\mathrm{s}^{-1}$, except $k_{0}$ and $k_{1}$, which are in $\mathrm{M}^{-1} \cdot \mathrm{s}^{-1}$.

implication of intracellular polyamines in the voltage-dependent block of GluK2(Q) (Bowie and Mayer, 1995), the amplitudes of currents recorded from an outside-out patch taken from a cell expressing GluK2(Q) were similar in absolute values at -80 and $+80 \mathrm{mV}$ when spermine was omitted from the patch pipette solution (Fig. 5D). For GluK3 receptors recorded in the same conditions, we could not detect currents at $+80 \mathrm{mV}$ shortly after outside-out patch formation (Fig. $5 E$ ). But as time passed, a current at $+80 \mathrm{mV}$ became detectable and progressively increased in amplitude (Fig. 5E). When we performed recordings in the presence of spermine ( $30 \mu \mathrm{M}$ free), no current was detectable at +80 $\mathrm{mV}$ throughout the recording period (Fig. $5 F$ ). The graph in Figure $5 G$ shows that, although the ratio of currents at the two voltages remained almost constant at a value of 1 for GluK2 channels, it reached this value for GluK3 in $\sim 20 \mathrm{~min}$, suggesting that spermine is bound much more tightly to GluK3, with a dissociation rate of several minutes. We estimated the spermine concentration necessary to block one-half of GluK3 channels at $+80 \mathrm{mV}$ by recording currents $10 \mathrm{~min}$ after outside-out patch formation: with $30 \mathrm{~nm}$ free spermine, we measured approximately one-half of the current ratio recorded with no spermine (Fig. $5 H$ ). Another estimate of spermine dissociation constant can be obtained by fitting the conductance-voltage relationship (Fig. $5 C$ ) with a Woodhull model of voltage-dependent block (see Materials and Methods) (Bowie and Mayer, 1995; Panchenko et al., 1999). This gave a dissociation constant at $0 \mathrm{mV} K_{\mathrm{d}(0)}$ of $42 \mathrm{~nm}$ for GluK3, comparable with the direct estimate (Fig. 5H), and 100-fold smaller than for GluK2 [3.8 $\mu \mathrm{M}$; similar to that of Bowie and Mayer (1995)].

\section{Molecular determinants of high-affinity spermine block of GluK3 receptors}

Which difference in the receptor structure causes the difference in spermine affinity for GluK2 and GluK3? It has been shown that spermine binding depends primarily on the conserved glutamine (590 in GluK2) that can be modified to an arginine by edition in GluA2, GluK1, and GluK2, abolishing spermine binding completely (Bowie and Mayer, 1995). Moreover, single-site mutagenesis of GluK2 at this site strongly affects spermine binding (Panchenko et al., 1999). Another important determinant of spermine binding is the negatively charged amino acid located four residues downstream of Q590, E594, in GluK2 (Panchenko
A
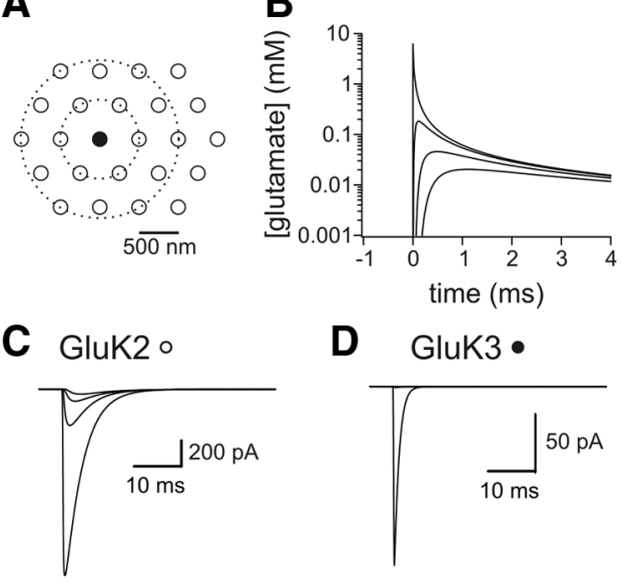

D GluK3 •

E GluA1ㅁ

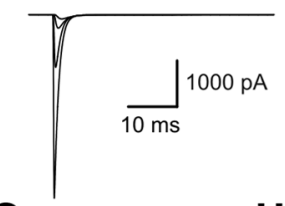

G

H
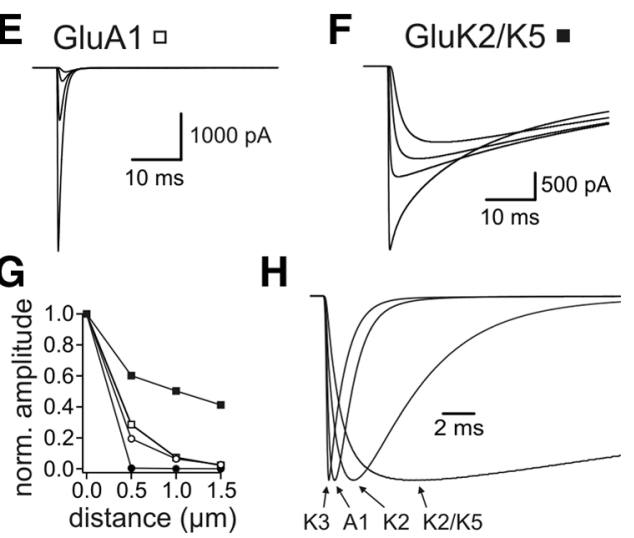

Figure 4. Model of receptor activation in a mossy fiber synapse. $\boldsymbol{A}$, Scheme of mossy fiber synapse containing 24 active zones. A vesicle releases glutamate at the black active zone and glutamate spreads to neighboring zones located $0.5,1 \mu \mathrm{m}$ apart (dotted lines). All zones are within $1.5 \mu \mathrm{m}$ of the release site. $\boldsymbol{B}$, Glutamate concentration at the release site, $500 \mathrm{~nm}, 1 \mu \mathrm{m}$, and $1.5 \mu \mathrm{m}$ apart. C, D, Activation of receptors by glutamate in the four locations, simulated with the models developed in this study (C, GluK2; D, GluK3), and in the studies by Robert and Howe (2003) ( $\boldsymbol{E}$, GluA1) and Barberis et al. (2008) (F, GluK2/ K5). The parameters of the simulations were 5000 receptors, $-80 \mathrm{mV}$ for all types of receptors. G, Current amplitude as a function of distance from release site for GluK2 (white circles), GluK3 (black circles), GluA1 (white squares), and GluK2/GluK5 (black squares). $\boldsymbol{H}$, Summed currents on the whole synapse (all 24 active zones) normalized to their peaks for GluK2, GluK3, GluA1, and GluK2/K5.

et al., 1999) that creates an electrostatic field important for the binding of the positively charged polyamines (Panchenko et al., 1999, 2001). However, binding of spermine itself to GluK2 has also a strong hydrophobic component and is spread on many residues (Cu et al., 1998; Panchenko et al., 2001). In this region, the amino acid sequence is much conserved between GluK2 and GluK3, and only two residues are different: M587 (V585 in GluK2) and S589 (A587 in GluK2). These residues are unique to GluK3 among AMPA/kainate receptors (Fig. 6A).

To test for their implication in the high-affinity spermine binding, these residues were mutated in GluK3 [GluK3(M587V,S589A)]. As shown on conductance-voltage curves, mutation of these two residues abolished high-affinity binding, and the receptor properties matched those of GluK2 at negative potentials (Fig. 6B). Mutation of only one of these residues gave intermediate behaviors (Fig. 6C), showing that both residues are necessary for highaffinity spermine binding. We verified that the mutants that contained the GluK3 extracellular domain were blocked by the selective GluK3 antagonist UBP310 (Perrais et al., 2009) and had 
A

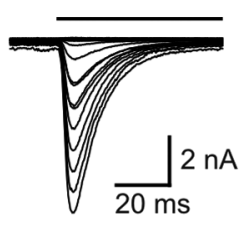

B

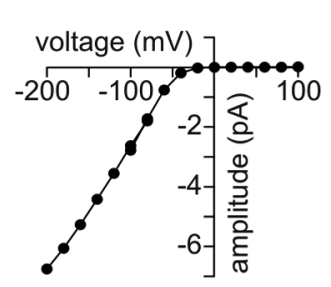

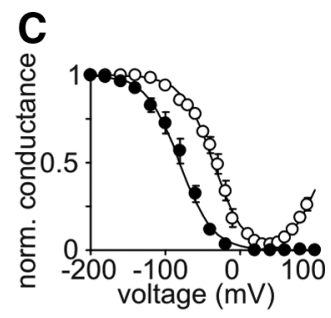

$F$

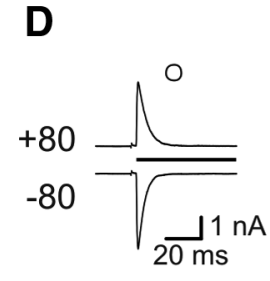

E
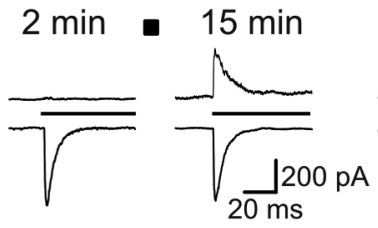

$2 \min$

- $18 \mathrm{~min}$
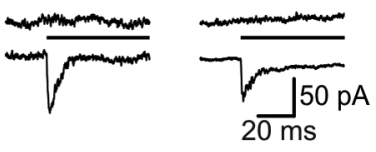

G

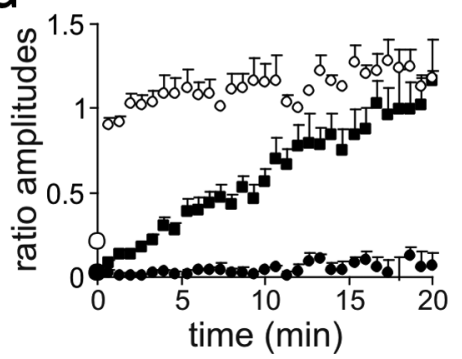

H

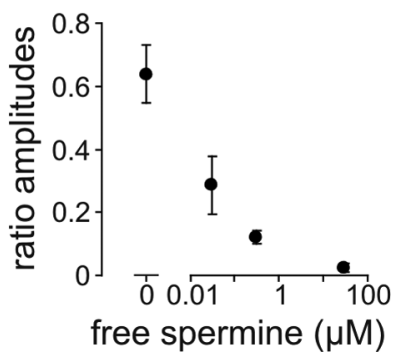

Figure 5. GluK3 receptors show very strong inward rectification because of high-affinity binding of intracellular spermine. $A$, Currents evoked by glutamate $(30 \mathrm{~mm})$ on a cell expressing GluK3 at potentials ranging from -200 to $+100 \mathrm{mV}$ in $20 \mathrm{mV}$ increments. The black bar shows the time of glutamate application. Note that, at -80 and $-100 \mathrm{mV}$, currents are evoked twice (see Materials and Methods). $\boldsymbol{B}$, Amplitude of currents shown in $\boldsymbol{A}$ as a function of holding voltage. $\boldsymbol{C}$, Conductance normalized to 1 at $-200 \mathrm{mV}$ for GluK3-expressing cells (black circles; $n=8$ ) and GluK2(Q)-expressing cells (white circles; $n=5$ ). For GluK2(Q)expressing cells, voltage above $-80 \mathrm{mV}$ was stepped in $10 \mathrm{mV}$ increments. Data could be fit (lines) with single sigmoidal function for GluK3 $\left(V_{\text {half }}=-81 \mathrm{mV}\right)$ and the sum of two sigmoids for GluK2 ( $V_{\text {half }}$ of -35 and $\left.+112 \mathrm{mV}\right)$. D. Currents evoked by glutamate (black bar) at $-80 \mathrm{mV}$ (bottom trace) and $+80 \mathrm{mV}$ (top trace) on an outside-out patch pulled from a cell expressing GluK2(Q), 2 min after patch formation. The pipette solution contained ATP but no spermine. $\boldsymbol{E}$, Same as in $\boldsymbol{D}$, on a patch pulled from a cell expressing GluK3, 2 min (left traces) and $15 \mathrm{~min}$ after patch formation. The pipette solution contained ATP but no spermine. $\boldsymbol{F}$, Same as in $\boldsymbol{E}$, but with a pipette solution containing $100 \mu \mathrm{m}$ spermine and $4 \mathrm{~mm}$ ATP. Even $18 \mathrm{~min}$ after patch formation, no current is detected at $+80 \mathrm{mV}$. G, Plot of the ratio of current amplitudes recorded first at $-80 \mathrm{mV}$, and then 20 s later at $+80 \mathrm{mV}$, versus time after patch formation, for patches pulled from cells expressing GluK2(Q) (white circles; $n=5)$, GluK3 (black squares; $n=$ 8), and GluK3 with $100 \mu \mathrm{m}$ spermine and $4 \mathrm{~mm} \mathrm{ATP} \mathrm{(black} \mathrm{circles;} n=7$ ). The large white and black circles at time 0 represent the ratios measured during whole-cell recordings for cells expressing GluK2(Q) and GluK3, respectively. $\boldsymbol{H}$, Ratio of amplitudes measured as in $\mathbf{G}$ 10-12 min after patch formation, with various concentrations of free spermine in the pipette solution. Error bars indicate SEM.

slower decay kinetics than the ones containing the GluK2 extracellular domain (Fig. 6D). However, the reverse mutant receptor GluK2(V585M,A587S) resembled the GluK2 wild-type receptor in all aspects (Fig. 6C,D). Therefore, these two residues are not sufficient to impart high-affinity spermine binding to the GluK2 receptor. There are four more residues located between transmembrane domain 1 and Q590 that differ between the two receptors: D562, A563, G569, and E571, that could be part of the spermine binding site. But again, the mutant receptor GluK2(DAGEMS), with all six residues mutated, behaved like wild-type GluK2 (Fig. 6C). Finally, a chimeric receptor composed of GluK2 in extracellular domains, and GluK3 in transmembrane and intracellular domains (termed $\mathrm{GluK} 2 \mathrm{e} / 3_{\mathrm{i}}$ ), also displayed properties identical with GluK2 wild type (Fig. $6 C$ ). What could then create the high-affinity spermine binding site? We hypothesized that the extracellular portion, although not part of the binding site, could change the conformation of the channel and thus the high-affinity spermine binding site. To test this, we first constructed a mutant chimeric receptor composed of the extracellular portion of GluK3 and the transmembrane and intracel- lular portions of GluK2 (GluK3 $\left.3_{\mathrm{e}} / \mathrm{K} 2_{\mathrm{i}}\right)$. As expected, this receptor behaved like the wild-type GluK2 receptor regarding spermine sensitivity (Fig. 6C). But when the two amino acids V587 and A589 were mutated for $\mathrm{M}$ and $\mathrm{S}$, respectively, the high-affinity spermine binding site was restored (Fig. 6C). Therefore, to change the affinity of spermine binding from the GluK2 to the GluK3 receptor, two conditions must be fulfilled: the two amino acids M587 and S589 must be present, and the extracellular portion of GluK3 must alter the conformation of the channel portion, in which the spermine binding site lies.

\section{Spermine sensitivity of GluK2/K3 heteromeric receptors}

In the brain, GluK3 receptor subunits are probably associated with other subunits, such as GluK2 at mossy fiber synapses (Pinheiro et al., 2007). Therefore, we determined the spermine sensitivity of receptors composed of GluK2(Q) and GluK3. We cotransfected HEK293 cells with GluK3 ${ }_{\mathrm{a}}$ and the GluK2 $2_{\mathrm{b}}(\mathrm{Q})$ C-terminal splice variant, which is less targeted to the plasma membrane than GluK2 2 a $(\mathrm{Q})$ as a homomeric receptor but has an identical kinetics and current-voltage relationship (Coussen et al., 2005). In addition, we blocked GluK3 homomeric receptors with $1 \mu \mathrm{M}$ UBP310, leaving GluK2/K3 heteromeric receptors and GluK2 homomeric receptors unaffected (Perrais et al., 2009). Between 10 and $60 \%$ of the current in control conditions was not blocked by the antagonist $(25 \pm 6 \% ; n=10)$, and the conductance-voltage relationship remained strongly rectificating in these conditions (Fig. 7A-C). For all 10 cells tested, regardless of the percentage of current resistant to UBP310, the values of $V_{\text {half }}$ were very close to those of GluK3 homomeric receptors $(-75.4 \pm 1.6 \mathrm{mV} ; p=0.08)$ (Fig. $7 D)$. Therefore, the association of GluK3 and GluK2 subunits leads to receptors that show high sensitivity to spermine. The lack of dependence of $V_{\text {half }}$ on the amount of current resistant to UBP310 suggests that even a minority of GluK3 subunits in a receptor, as probably occurs when little current is blocked by this antagonist, leads to high spermine sensitivity. Alternatively, assembly of GluK2 and GluK3 might be nonrandom, with a preference for heteromeric receptors composed of a defined number of subunits, as has been shown for GluA1-3 AMPA receptors (Mansour et al., 2001). In this case, the high sensitivity of GluK2/K3 to spermine tested here would be the one of a uniform population of receptors.

\section{Calcium permeability of GluK3 receptors}

Another key property for a receptor potentially regulating neurotransmitter release is its ability to pass calcium among other cations. AMPA/kainate receptors that are not edited at the Q/R site are permeable to calcium, and the GluK3 subunit is not edited 
(Lomeli et al., 1992). We determined the fractional calcium current by recording the charge going through receptors and the amount of calcium into the cell by fluorescence imaging with fura-2 (Burnashev et al., 1995; Jatzke et al., 2003). However, for reliable detection of calcium concentration changes with $1 \mathrm{~mm}$ fura-2 large charges going through the receptors are needed. Because GluK3 desensitization cannot be blocked by concanavalin A (Schiffer et al., 1997) or other means, we were unable to evoke on adhering cells large currents for sustained periods of time. Therefore, we turned to mutated receptors that show no desensitization because the interdomain interactions of the agonist binding domains are stabilized by disulfide bounds through cysteine residues (Weston et al., 2006). We used GluK3(H492C,L753C) (termed GluK3CC) and, for comparison, the nonedited GluK2(Y490C,L752C) (GluK2CC). When glutamate $(30 \mathrm{~mm})$ was applied to GluK3(CC)-expressing cells, the current evoked was sustained, although it displayed a small amplitude, in the 20-200 pA range (Fig. $8 A$ ). The small amplitude is probably attributable to the reduced ability of non-desensitizing kainate receptors to reach the plasma membrane, as was shown for GluK2 receptors (Priel et al., 2006). Like wild-type GluK3 receptors, GluK3(CC) receptors were blocked by 1 $\mu \mathrm{M}$ UBP310 (Fig. 8A), and the currentvoltage relationship was strongly rectifying with no outward currents at voltages up to $+100 \mathrm{mV}$ (Fig. $8 \mathrm{~B}$ ). Likewise, GluK2(CC) receptors were insensitive to $1 \mu \mathrm{M}$ UBP310 and showed a current-voltage relationship similar to wild-type GluK2 receptors (Fig. $8 C$ ). These results strongly suggest that mutant receptors have the same permeation properties as wild-type receptors.

In cells dialyzed with $1 \mathrm{~mm}$ fura-2, the application of glutamate evoked currents and concomitant decreases in fura-2 fluorescence, showing that both GluK2(CC) receptors (Fig. $8 D$ ) and GluK3(CC) receptors (Fig. $8 E$ ) are calcium permeable. We compared the relative calcium permeability of these receptors (see Materials and Methods) and that of wildtype GluK2 receptors, with currents evoked by $10 \mu \mathrm{M}$ domoate, which evoked a similar charge as mutant receptors at $-80 \mathrm{mV}$ (Fig. $8 F$ ). The fractional calcium permeability of the three types of receptors was not significantly different $(\sim 2.5 \%$; $p=0.45$ for GluK2 vs GluK2CC; $p=0.85$ for GluK2 vs GluK3CC) (Fig. 8G). Thus, we conclude that GluK3 receptors are likely to have the same calcium permeability as nonedited GluK2 receptors.

\section{Discussion}

In this study, we have characterized the atypical biophysical properties of GluK3 receptors that significantly depart from other AMPA/kainate receptors. We have shown that these recep- tors have a low sensitivity to glutamate, in large part because of accelerated kinetics of desensitization of partially bound receptors. Moreover, we have shown that GluK3 receptors have a very strong sensitivity to voltage because of a very high-affinity binding of intracellular spermine. Finally, we show that these receptors are permeable to calcium with similar selectivity to unedited GluK2 receptors. This study unravels specific biophysical properties of GluK3-containing receptors, further extending the repertoire of ionotropic glutamate receptor properties that dictates information processing at excitatory synapses.

\section{Activation of GluK3 receptors by glutamate}

AMPA/kainate receptors are activated by high concentrations of glutamate $\left(\mathrm{EC}_{50}, 0.5-10 \mathrm{~mm}\right.$ range $)$ and are desensitized by lower concentrations of glutamate (low micromolar range) (Heckmann et al., 1996; Häusser and Roth, 1997; Paternain et al., 1998; Robert and Howe, 2003; Robert et al., 2005), consistent with the idea that 


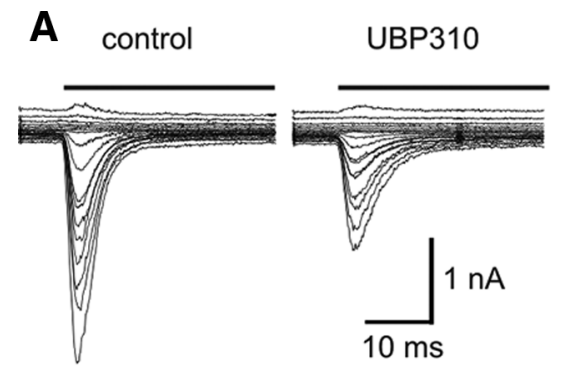

B
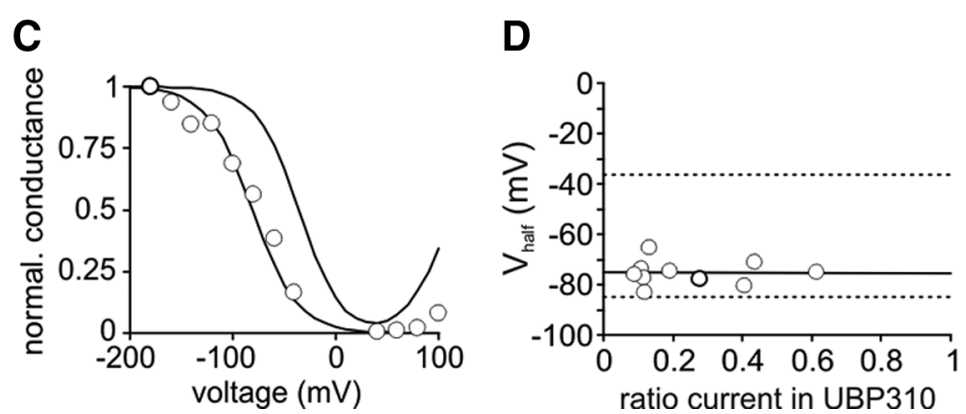

Figure 7. Spermine sensitivity of GluK2/GluK3 heteromeric receptors. A, Family of currents recorded from a cell transfected with GluK2 $_{b}(Q)$ and GluK $3_{a}$ at voltages ranging from -180 to $+100 \mathrm{mV}$. Left, In control conditions; right, with $1 \mu \mathrm{m}$ UBP310 added in the extracellular solutions, which blocks GluK3 homomeric receptors. The bars indicate the moment of glutamate application (30 $\mathrm{mm})$. $\boldsymbol{B}$, Plots of $I V$ curves obtained from the recordings in $\boldsymbol{A}$. Black circles, In control conditions; white circles, with UBP310. C, Normalized conductance versus voltage for the cell recorded in $\boldsymbol{A}$ and $\boldsymbol{B}$ in the presence of UBP310. Its voltage at half-block $V_{\text {half }}$ is $-78 \mathrm{mV}$, almost matching the values for GluK3 homomeric receptors (fits for GluK2 and GluK3 replotted from Fig. 5C). D, Values of $V_{\text {half }}$ for 10 cells as in $A$, plotted versus the fraction of current resistant to $1 \mu \mathrm{m}$ UBP310 at $-80 \mathrm{mV}$. The line represents the regression line with a slope of $-0.3 \mathrm{mV}$. The dotted lines represent values of $V_{\text {half }}$ for GluK2 and GluK3. oocytes (Bettler et al., 1992; Strutz et al., 2001) or adhering HEK293 cells (our own observation). Another consequence of this property is that modulating GluK3 receptor desensitization would also affect its sensitivity to glutamate. This raises the intriguing possibility that associated proteins like Neto2, if they decrease desensitization of GluK3 as they do for GluK2 receptors (Zhang et al., 2009), could affect glutamate sensitivity.

Native GluK3 receptors in mossy fiber terminals are likely composed of GluK2 as well (Pinheiro et al., 2007). Therefore, it would be important to assess the kinetic properties of recombinant heteromeric GluK2/K3 receptors. The glutamate sensitivity of receptors recorded in cells coexpressing GluK $2_{\mathrm{b}}$ and GluK3 $3_{\mathrm{a}}$ is close to that of homomeric GluK3 receptors (Pinheiro et al., 2007), suggesting that in heteromeric receptors the GluK3 dominates the kinetic properties. However, a detailed analysis of currents evoked by 1 or $3 \mathrm{~mm}$ glutamate in cells expressing both subunits was not possible, since at this concentration even a minor population of GluK2 $2_{\mathrm{b}}$ homomeric receptors would interfere with the measurements. desensitization requires only one bound glutamate, whereas channel opening requires at least two bound glutamate molecules (Robert and Howe, 2003). Although qualitatively similar, the behavior of AMPA and kainate receptors show striking differences. In particular, the desensitization kinetics of recombinant GluA1, 2 , and 4 do not depend on glutamate concentration (Robert and Howe, 2003; Robert et al., 2005), whereas GluK2 activation and desensitization kinetics is much slower at low concentration. The situation is opposite for GluK3 receptors. Using kinetic models with an architecture developed for AMPA (Robert and Howe, 2003) and kainate receptors (Barberis et al., 2008) consisting of four bound states, three open states, and four desensitized states (plus three secondary desensitized states), we could fit our experimental results with essentially two modifications compared with AMPA receptors: (1) decrease the binding rate of the first glutamate molecule $k_{0}$, reflecting a positive allosteric mechanism for glutamate binding; (2) decrease (for GluK2) or increase (for GluK3) the entry into desensitization from the singly bound state $\mathrm{R} 1$ and in the case of GluK3, doubly bound state R2, to reflect the changes in desensitization kinetics with glutamate concentration. Strikingly, the very different properties of GluK2 and GluK3 could be reproduced with very little change in the binding and unbinding rates $k_{0}, k_{1}$, and $k_{-1}$, suggesting that the main differences between the two receptors lie in the stability of the ligand binding domain dimer interface, which is essential for desensitization (Weston et al., 2006) and in the coupling between binding and channel opening, rather than in binding of glutamate to the receptor. These kinetic properties explain not only the low glutamate sensitivity of GluK3 receptors but also that these receptors can only be activated by fast transients of glutamate. This behavior can explain why it has not been possible to record GluK3mediated currents with slow application systems on Xenopus

\section{Properties of the GluK3 channel pore}

We have demonstrated that GluK3 receptors are sensitive to intracellular spermine, with an estimated $K_{\mathrm{d}(0)}$ of $42 \mathrm{nM}, 50$-fold greater than other nonedited AMPA/kainate receptors (Bowie and Mayer, 1995). We found that this high affinity is attributable to two key residues, M587 and S589, that are unique to GluK3 receptors among other AMPA/kainate receptors. However, exchanging these residues with the corresponding ones in GluK2 receptors did not yield to the same high-affinity binding site. Thus, another factor, such as a conformational change caused by the extracellular portion of GluK3, is necessary to increase affinity. The high spermine affinity could be linked to the specific gating properties of GluK3 (see above). However, we note that GluK3(CC) receptors, in which desensitization is mostly absent, are equally sensitive to spermine, arguing against a strong link between GluK3 desensitization and high-affinity spermine binding.

The fit of current-voltage curves with sigmoid functions, with the two parameters $V_{\text {half }}$ and $k_{b}$, can give information about the spermine binding site. The highly decreased $V_{\text {half }}$ (from $-35 \mathrm{mV}$ for GluK2 to $-81 \mathrm{mV}$ for GluK3) is consistent with a high spermine affinity. However, the similar $k_{b}$, which reflects the voltage sensitivity of the block, suggests that the location of the binding site within the channel is similar for both receptors (Bowie and Mayer, 1995). Systematic mutations of the residues in the M2 loop on GluK2 receptors have been performed to characterize the spermine binding site (Panchenko et al., 1999, 2001). Most of the mutations into alanine or tryptophan led to either no change or decrease in affinity for spermine, suggesting that single amino acid mutations do not change the overall structure of the channel. Interestingly, one mutant, Q590W, led to a very large increase in spermine affinity, with a $K_{\mathrm{d}(0)}$ of 190 pM. The interpretation of 


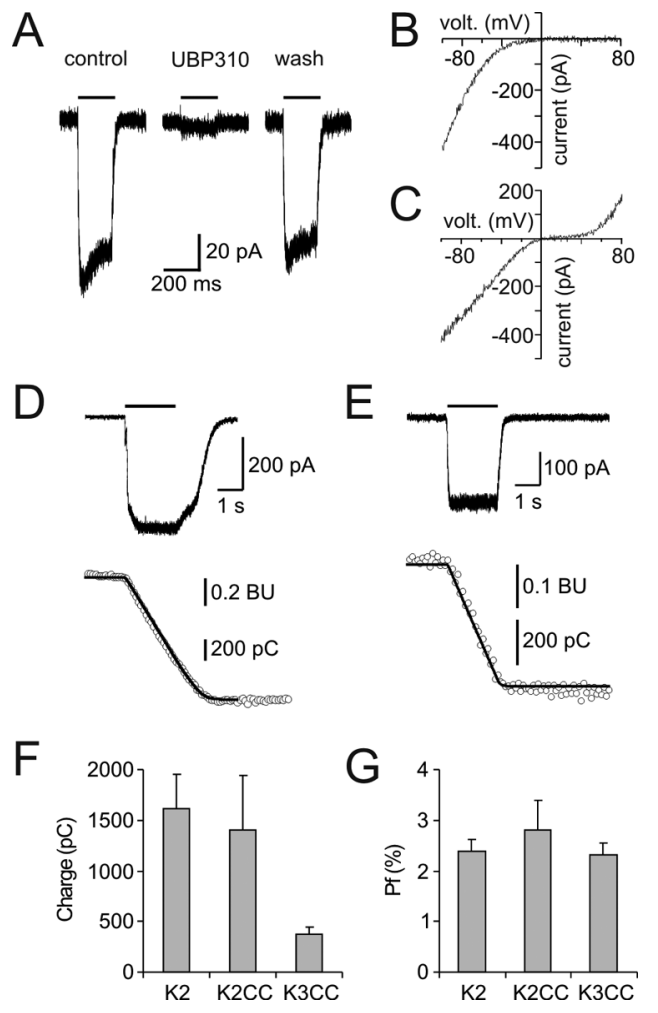

Figure 8. Calcium permeability of GluK3 receptors. $A$, Currents recorded from a cell transfected with the mutant receptor GluK3(H492C,L753C). Glutamate ( $30 \mathrm{~mm}$ ) is applied for $200 \mathrm{ms,}$ before, during, and after the application of $1 \mu \mathrm{M}$ UBP310. The cell is held at $-80 \mathrm{mV}$. $B$, Current-voltage relationship for the same cell as in $A$ obtained with a voltage ramp between -100 and $+80 \mathrm{mV}$. C, Current-voltage relationship obtained as in $\boldsymbol{B}$ for a cell transfected with GluK2(Y490C,L752C). D, Simultaneous recordings of currents and fura-2 fluorescence evoked by glutamate application (30 mm) on a cell expressing GluK2(Y490C,L752C). Fura-2 fluorescence (excited by an excitation light at $380 \mathrm{~nm}$ ) is expressed in bead units (white circles). The charge (in picocoulombs) corresponding to the current recorded on top is superimposed on the fluorescence measure. For this cell, we measured a charge of $\Delta Q=-1150 \mathrm{pC}$ for a fluorescence change of $\Delta F_{380}=-0.912 \mathrm{BU}$. This converts into a fractional calcium permeability of $3.7 \%$. $\boldsymbol{E}$, Same as in D for a cell expressing GluK3(H492C,L753C). For this cell, we measured a charge of $\Delta Q=-555 \mathrm{pC}$ for a fluorescence change of $\Delta F_{380}=-0.306 \mathrm{BU}$. This converts into a fractional calcium permeability of $2.6 \%$. $F$, Average charge evoked by agonist applications [30 mм glutamate for mutant receptors; $10 \mu \mathrm{m}$ domoate for GluK2(Q); $2 \mathrm{~s}$ ] at $-80 \mathrm{mV}$. G, Average values of fractional calcium permeability $P_{\mathrm{f}}$. There was no statistical difference between the receptors $(t$ test, $p>0.4)$. Error bars indicate SEM.

this result has been that the bulky tryptophan residues set an aromatic ring in the pore cavity that favors spermine binding (Panchenko et al., 2001). It is thus conceivable that, in GluK3 receptors, the pore cavity is more closed than in GluK2 receptors and that the differences in residues M587 and S589 in GluK3 establish a high-affinity spermine binding site. However, the similar channel conductances and calcium permeability for these two kainate receptors argue against major structural differences.

Edition of the glutamine into an arginine for GluK2, GluK1, and GluA2 abolishes spermine sensitivity (Bowie and Mayer, 1995) as well as calcium permeability (Burnashev et al., 1995), suggesting that these two properties are correlated. Indeed, GluA1 receptors have a higher affinity for spermine than GluK2 receptors (Bowie and Mayer, 1995) and a higher permeability for calcium (Burnashev et al., 1995). However, we show here that, despite a much higher affinity for spermine, GluK3 receptors do not show significantly different calcium permeability from that of GluK2 receptors. This result clearly shows that these two properties can be decoupled. Previous results on mutant receptors have shown possibilities for a similar uncoupling. GluA3 mutated in the Q/R site to an $\mathrm{N}$ gave calcium permeable receptors with no rectification (Dingledine et al., 1992). Moreover, GluA2 receptor mutants (N619C and N619K) have much decreased calcium permeability, but their rectification properties are similar to wild-type receptors, suggesting that their spermine sensitivity is the same (Jatzke et al., 2003). In a more physiological situation, addition of stargazin to AMPA receptors decreases their sensitivity to spermine without changing their calcium permeability (Soto et al., 2007). Therefore, these two channel properties are related but rely on different mechanisms.

\section{Implications for GluK3 receptor function in synaptic transmission}

The two characteristic features of GluK3 receptors, low sensitivity to glutamate and high affinity for spermine, could have profound effects on signaling mediated by these receptors at excitatory synapses. As discussed above, these receptors can only be activated by large and fast transients of glutamate. In synapses, this would correspond to receptors close to release sites. These receptors would be insensitive to tonic glutamate application or glutamate spillover from neighboring release sites. The GluK3 is strongly expressed in several brain areas (Bettler et al., 1992) and could participate to postsynaptic as well as presynaptic receptors. To date, the involvement of GluK3 in synaptic transmission has been demonstrated only in the presynaptic regulation of hippocampal mossy fiber synapses (Pinheiro et al., 2007). We have shown here that the simulated currents induced by a plausible model of glutamate release at the mossy fiber synapse showed that GluK3 receptors were activated only at the release site, whereas GluK2, GluA1, and especially GluK2/K5 receptors were activated significantly away from the release site (Fig. 4). Consequently, the average glutamate concentration that causes receptor activation at this synapse would be higher for presynaptic, GluK3-containing receptors than postsynaptic AMPA and kainate receptors. This prediction is consistent with the lack of effect of the low-affinity competitive antagonist kynurenate on presynaptic modulation of glutamate release by GluK3-containing kainate receptors at concentrations that mostly block postsynaptic currents (Pinheiro et al., 2007).

The high affinity for spermine of GluK3 and GluK2/K3 receptors would lead to receptors in neurons that are blocked at very negative potentials. With the concentration of spermine found in neuronal dendrites (Donevan and Rogawski, 1995; Koh et al., 1995), receptors would be blocked by one-half already at -80 $\mathrm{mV}$. Around $-40 \mathrm{mV}$, the action potential threshold, these receptors would be almost completely blocked by spermine. However, if these receptors act in presynaptic terminals, such as hippocampal mossy fibers, several factors need to be appreciated. The spermine concentration in nerve terminals is currently unknown and could be lower than in dendrites. A high-affinity binding site would warrant voltage-dependent modulation even with lower intracellular polyamine concentration. Furthermore, mossy fiber nerve terminals have a hyperpolarized resting potential $(-80 \mathrm{mV})$ (Alle and Geiger, 2006), and the release of glutamate would occur after the action potential has invaded the terminal, during the following hyperpolarization. Therefore, at a low frequency of presynaptic action potentials, the activation of GluK3 receptors would be maximal. Indeed, the effect of presynaptic kainate receptors is maximal at a spike frequency between 1 and $20 \mathrm{~Hz}$ (Sachidhanandam et al., 2009). Presynaptic GluK3 
receptors would thus behave as low-pass filters, potentiating glutamate release at low frequency, but being inactivated when the presynaptic cells are depolarized in the dendrites and in the axonal compartment (Alle and Geiger, 2006).

As discussed above, GluK3 receptors are activated by large and fast glutamate transients, and only minimally by glutamate diffusing long distances away from the release site. Moreover, open and closed channel block by intracellular spermine, delaying receptor activation (Bowie et al., 1998), and leading to increased block as the terminal is depolarized, would further reduce activation away from the release site. Therefore, potentiation of glutamate release at mossy fibers may involve only sites where glutamate release occurred. However, these sites compose only a minority of release sites and the short-term facilitation likely involves glutamate release at previously silent sites (Pinheiro and Mulle, 2008). Alternatively, activation of presynaptic kainate receptors at the release site could initiate an intracellular cascade that would propagate to other release sites. Likely candidates include calcium stores that are present at mossy fibers (Scott et al., 2008) and modulate short-term plasticity (Lauri et al., 2003; Scott et al., 2008).

\section{References}

Alle H, Geiger JR (2006) Combined analog and action potential coding in hippocampal mossy fibers. Science 311:1290-1293.

Barberis A, Sachidhanandam S, Mulle C (2008) GluR6/KA2 kainate receptors mediate slow-deactivating currents. J Neurosci 28:6402-6406.

Barbour B, Häusser M (1997) Intersynaptic diffusion of neurotransmitter. Trends Neurosci 20:377-384.

Bettler B, Egebjerg J, Sharma G, Pecht G, Hermans-Borgmeyer I, Moll C, Stevens CF, Heinemann S (1992) Cloning of a putative glutamate receptor: a low affinity kainate-binding subunit. Neuron 8:257-265.

Bowie D (2002) External anions and cations distinguish between AMPA and kainate receptor gating mechanisms. J Physiol 539:725-733.

Bowie D, Lange GD (2002) Functional stoichiometry of glutamate receptor desensitization. J Neurosci 22:3392-3403.

Bowie D, Mayer ML (1995) Inward rectification of both AMPA and kainate subtype glutamate receptors generated by polyamine-mediated ion channel block. Neuron 15:453-462.

Bowie D, Lange GD, Mayer ML (1998) Activity-dependent modulation of glutamate receptors by polyamines. J Neurosci 18:8175-8185.

Burnashev N, Zhou Z, Neher E, Sakmann B (1995) Fractional calcium currents through recombinant GluR channels of the NMDA, AMPA and kainate receptor subtypes. J Physiol 485:403-418.

Contractor A, Swanson G, Heinemann SF (2001) Kainate receptors are involved in short- and long-term plasticity at mossy fiber synapses in the hippocampus. Neuron 29:209-216.

Cossart R, Epsztein J, Tyzio R, Becq H, Hirsch J, Ben-Ari Y, Crépel V (2002) Quantal release of glutamate generates pure kainate and mixed AMPA/ kainate EPSCs in hippocampal neurons. Neuron 35:147-159.

Coussen F, Perrais D, Jaskolski F, Sachidhanandam S, Normand E, Bockaert J, Marin P, Mulle C (2005) Coassembly of two GluR6 kainate receptor splice variants within a functional protein complex. Neuron 47:555-566.

Cu C, Bähring R, Mayer ML (1998) The role of hydrophobic interactions in binding of polyamines to non NMDA receptor ion channels. Neuropharmacology 37:1381-1391.

Dingledine R, Hume RI, Heinemann SF (1992) Structural determinants of barium permeation and rectification in non-NMDA glutamate receptor channels. J Neurosci 12:4080-4087.

Donevan SD, Rogawski MA (1995) Intracellular polyamines mediate inward rectification of $\mathrm{Ca}^{2+}$-permeable alpha-amino-3-hydroxy-5-methyl4-isoxazolepropionic acid receptors. Proc Natl Acad Sci US A 92:9298-9302.

Häusser M, Roth A (1997) Dendritic and somatic glutamate receptor channels in rat cerebellar Purkinje cells. J Physiol 501:77-95.

Heckmann M, Bufler J, Franke C, Dudel J (1996) Kinetics of homomeric GluR6 glutamate receptor channels. Biophys J 71:1743-1750.

Jatzke C, Hernandez M, Wollmuth LP (2003) Extracellular vestibule deter- minants of $\mathrm{Ca}^{2+}$ influx in $\mathrm{Ca}^{2+}$-permeable AMPA receptor channels. J Physiol 549:439-452.

Koh DS, Burnashev N, Jonas P (1995) Block of native $\mathrm{Ca}^{2+}$-permeable AMPA receptors in rat brain by intracellular polyamines generates double rectification. J Physiol 486:305-312.

Köhler M, Burnashev N, Sakmann B, Seeburg PH (1993) Determinants of $\mathrm{Ca}^{2+}$ permeability in both TM1 and TM2 of high affinity kainate receptor channels: diversity by RNA editing. Neuron 10:491-500.

Kwon HB, Castillo PE (2008) Role of glutamate autoreceptors at hippocampal mossy fiber synapses. Neuron 60:1082-1094.

Lauri SE, Bortolotto ZA, Nistico R, Bleakman D, Ornstein PL, Lodge D, Isaac JT, Collingridge GL (2003) A role for $\mathrm{Ca}^{2+}$ stores in kainate receptordependent synaptic facilitation and LTP at mossy fiber synapses in the hippocampus. Neuron 39:327-341.

Lerma J (2006) Kainate receptor physiology. Curr Opin Pharmacol 6:89-97.

Lomeli H, Wisden W, Köhler M, Keinänen K, Sommer B, Seeburg PH (1992) High-affinity kainate and domoate receptors in rat brain. FEBS Lett 307:139-143.

Mansour M, Nagarajan N, Nehring RB, Clements JD, Rosenmund C (2001) Heteromeric AMPA receptors assemble with a preferred subunit stoichiometry and spatial arrangement. Neuron 32:841-853.

Marchal C, Mulle C (2004) Postnatal maturation of mossy fiber excitatory transmission in mouse CA3 pyramidal cells: a potential role for kainate receptors. J Physiol 561:27-37.

Nielsen TA, DiGregorio DA, Silver RA (2004) Modulation of glutamate mobility reveals the mechanism underlying slow-rising AMPAR EPSCs and the diffusion coefficient in the synaptic cleft. Neuron 42:757-771.

Panchenko VA, Glasser CR, Partin KM, Mayer ML (1999) Amino acid substitutions in the pore of rat glutamate receptors at sites influencing block by polyamines. J Physiol 520:337-357.

Panchenko VA, Glasser CR, Mayer ML (2001) Structural similarities between glutamate receptor channels and $\mathrm{K}^{+}$channels examined by scanning mutagenesis. J Gen Physiol 117:345-360.

Paternain AV, Rodríguez-Moreno A, Villarroel A, Lerma J (1998) Activation and desensitization properties of native and recombinant kainate receptors. Neuropharmacology 37:1249-1259.

Paternain AV, Cohen A, Stern-Bach Y, Lerma J (2003) A role for extracellular $\mathrm{Na}^{+}$in the channel gating of native and recombinant kainate receptors. J Neurosci 23:8641-8648.

Perrais D, Pinheiro PS, Jane DE, Mulle C (2009) Antagonism of recombinant and native GluK3-containing kainate receptors. Neuropharmacology 56:131-140.

Pinheiro P, Mulle C (2006) Kainate receptors. Cell Tissue Res 326:457-482.

Pinheiro PS, Mulle C (2008) Presynaptic glutamate receptors: physiological functions and mechanisms of action. Nat Rev Neurosci 9:423-436.

Pinheiro PS, Perrais D, Coussen F, Barhanin J, Bettler B, Mann JR, Malva JO, Heinemann SF, Mulle C (2007) GluR7 is an essential subunit of presynaptic kainate autoreceptors at hippocampal mossy fiber synapses. Proc Natl Acad Sci U S A 104:12181-12186.

Priel A, Selak S, Lerma J, Stern-Bach Y (2006) Block of kainate receptor desensitization uncovers a key trafficking checkpoint. Neuron 52:1037-1046.

Robert A, Howe JR (2003) How AMPA receptor desensitization depends on receptor occupancy. J Neurosci 23:847-858.

Robert A, Armstrong N, Gouaux JE, Howe JR (2005) AMPA receptor binding cleft mutations that alter affinity, efficacy, and recovery from desensitization. J Neurosci 25:3752-3762.

Rollenhagen A, Sätzler K, Rodríguez EP, Jonas P, Frotscher M, Lübke JH (2007) Structural determinants of transmission at large hippocampal mossy fiber synapses. J Neurosci 27:10434-10444.

Sachidhanandam S, Blanchet C, Jeantet Y, Cho YH, Mulle C (2009) Kainate receptors act as conditional amplifiers of spike transmission at hippocampal mossy fiber synapses. J Neurosci 29:5000-5008.

Savtchenko LP, Rusakov DA (2004) Glutamate escape from a tortuous synaptic cleft of the hippocampal mossy fiber synapse. Neurochem Int 45:479-484.

Schiffer HH, Swanson GT, Heinemann SF (1997) Rat GluR7 and a carboxyterminal splice variant, GluR7b, are functional kainate receptor subunits with a low sensitivity to glutamate. Neuron 19:1141-1146. 
Schmitz D, Mellor J, Breustedt J, Nicoll RA (2003) Presynaptic kainate receptors impart an associative property to hippocampal mossy fiber longterm potentiation. Nat Neurosci 6:1058-1063.

Scott R, Lalic T, Kullmann DM, Capogna M, Rusakov DA (2008) Target-cell specificity of kainate autoreceptor and $\mathrm{Ca}^{2+}$-store-dependent short-term plasticity at hippocampal mossy fiber synapses. J Neurosci 28:1313913149.

Soto D, Coombs ID, Kelly L, Farrant M, Cull-Candy SG (2007) Stargazin attenuates intracellular polyamine block of calcium-permeable AMPA receptors. Nat Neurosci 10:1260-1267.

Strutz N, Villmann C, Thalhammer A, Kizelsztein P, Eisenstein M, Teichberg VI, Hollmann M (2001) Identification of domains and amino acids involved in GluR7 ion channel function. J Neurosci 21:401-411.

Swanson GT, Feldmeyer D, Kaneda M, Cull-Candy SG (1996) Effect of
RNA editing and subunit co-assembly single-channel properties of recombinant kainate receptors. J Physiol 492:129-142.

Traynelis SF, Wahl P (1997) Control of rat GluR6 glutamate receptor open probability by protein kinase A and calcineurin. J Physiol 503:513-531.

Watanabe S, Kusama-Eguchi K, Kobayashi H, Igarashi K (1991) Estimation of polyamine binding to macromolecules and ATP in bovine lymphocytes and rat liver. J Biol Chem 266:20803-20809.

Weston MC, Schuck P, Ghosal A, Rosenmund C, Mayer ML (2006) Conformational restriction blocks glutamate receptor desensitization. Nat Struct Mol Biol 13:1120-1127.

Zhang W, St-Gelais F, Grabner CP, Trinidad JC, Sumioka A, MorimotoTomita M, Kim KS, Straub C, Burlingame AL, Howe JR, Tomita S (2009) A transmembrane accessory subunit that modulates kainate-type glutamate receptors. Neuron 61:385-396. 